\title{
Comparison between Average Time Taken in Different Groups of Cattle under Various Activities at Different Dairy Farm in Jaipur District, Rajasthan, India
}

\author{
Rashmi Bhinda ${ }^{1}$, R.P. Jat ${ }^{1}$, Bajarang Lal Choudhary ${ }^{2 *}$ and Basant Kumar Bhinchhar ${ }^{2}$ \\ ${ }^{1}$ Department of livestock production management, SKNAU, Jobner, Jaipur, India \\ ${ }^{2}$ Department of Animal Husbandry and Dairying, IAS, BHU, Varanasi, India \\ *Corresponding author
}

\section{A B S T R A C T}

The study on Labour utilization pattern in management of various categories of cattle was undertaken at three dairy farms SKN COA, dairy farm, Jobner, Agrim dairy farm, Kumbhpura and Mahila dairy farm, Harnath ki dhani, for a period of 90 days to find out the time taken by the labour for various activities on the farms viz. milking, cleaning, feeding and miscellaneous work. Animals were divided into 6 groups i.e. $\mathrm{G}_{1}$ (milch cows), $\mathrm{G}_{2}$ (pregnant cows), $\mathrm{G}_{3}$ (dry cows), $\mathrm{G}_{4}$ (calves), $\mathrm{G}_{5}$ (heifers) and $\mathrm{G}_{6}$ (bull and bullocks). The average total working time in milking operations was more effective on the basis of less taken time (min/cow/day) at Agrim dairy farm (14.05 \pm 0.048$)$ as compared to Mahila $(14.34 \pm 0.130)$ and SKN COA, dairy farm $(16.51 \pm 0.076)$. The average time in cleaning operation was $8.30 \pm 0.43,8.68 \pm 0.46$ and $9.09 \pm 0.45 \mathrm{~min} / \mathrm{animal} / \mathrm{day}$ at Agrim, Mahila and SKN COA, dairy farm, respectively. The average time (min/animal/day) taken in feeding and watering was more effective at Agrim dairy farm $(8.85 \pm 0.44)$ than Mahila $(9.19 \pm 0.48)$ and SKN COA, dairy farm $(9.96 \pm 0.68)$. The average time (min/animal/day) taken in miscellaneous work was more effective at Agrim dairy farm (3.44 \pm 1.33$)$ as compared to Mahila (3.70 \pm 1.29$)$ and SKN COA, dairy farm (4.63 \pm 1.65$)$. The average total working time (min/animal/day) in all activities was lowest at Agrim dairy farm (34.64) as compared to Mahila dairy farm (35.91) and SKN COA, dairy farm (40.19). The average total working time ( $\mathrm{min} /$ labour/day) taken for various activities was highest at Agrim (278.30) as compared to Mahila (223.36) and SKN COA, dairy farm (175.24). The average total working time (min/animal/day) was highest in $\mathrm{G}_{1}$ (34.93), followed by $\mathrm{G}_{6}(27.22), \mathrm{G}_{2}$ (22.21), $G_{5}$ (20.44) $G_{3}(16.85)$ and $G_{4}$ (15.98) groups at most effective Agrim dairy farm. Average manage of animal/labour/day in $\mathrm{G}_{1}, \mathrm{G}_{2}, \mathrm{G}_{3}, \mathrm{G}_{4}, \mathrm{G}_{5}$ and $\mathrm{G}_{6}$ groups at Agrim dairy farm was $13.74,21.61,28.48,30.03,23.48$ and 17.64 , respectively. It is shows that one labour can manage maximum 13 milch cows per day. Therefore, it is concluded that the labour efficiency of Agrim dairy farm was better as compared to other dairy farms because total working time/animal/day was more effective as well as total working time/labour/day was also more and one labour could manage more number of animals at Agrim dairy farm. The labour utilization pattern for milking process was maximum, followed by the feeding, cleaning and miscellaneous works.

\section{Introduction}

Management plays an important role in maintaining health and particularly growth in the cattle and buffalo. Livestock sector is an important sub-sector of the agriculture of
Indian economy. It forms an important livelihood activity for most of the farmers, supporting agriculture in the form of critical inputs, contributing to the health and nutrition 
of the household, supplementing incomes, offering employment opportunities, and finally being a dependable "bank on hooves" in times of need. The total bovine population is 299.90 million which accounts for 58.57 percent of the total livestock (512.05 million) in the country. Out of total bovines, cattle account for 190.90 million (Anonymous, 2012). Livestock production offers an avenue for food security oriented self-employment to unemployment youths and women. The labour requirement of dairy farm depends upon various management activities conduct at the farm. Labour cost comes next to the feed cost for management of dairy farm, hence, greater the labour efficiency, larger is the returns from dairying. In our country, labour is either under-utilized or over-utilized thus organization or management of this resource influences proper utilization of money and material invested in dairy farming (Legha et al., 2000). Effective utilization of man power along with other inputs is a must to increase the productivity and profitability of dairy farming. So a good role is "Make the plan to fit the man." Cost of milk production depends upon efficient utilization of man power, reduction of feed cost etc. Milking, feeding and cleaning are most labour oriented operations at a dairy farm. The time study is fundamentally aimed to draw scientific conclusions which are always better than layman's experience. With this study, efficiency of the labour utilization may be increased to a considerable extent. Standard norms for labour requirements for different dairy farm operations are available. Some old studies by (Rawat et al., 1973; Singh and Dave, 1985; Devarajulu et al., 1989) on dairy farm work analysis may not fit into present day context because of revision of wages and labour laws. Information on labour input for carrying out day to day operations at dairy farm viz. milking, feeding, cleaning of shed, washing, and miscellaneous work and also on factors influencing the same is scanty (Grewal et al., 1980). Hence, it is required to estimate the time requirement for various dairy farm operations for different categories of animals for efficient utilization of man power.

\section{Materials and Methods}

\section{Location}

The present study on labour utilization pattern in management of various categories of cattle on different dairy farms was carried out at S.K.N. College of Agriculture, dairy farm Jobner (H.Q.), Phulera Tehsil, Agrim dairy farm, Kumbhpura (80 km. from H.Q.), Chomu Tehsil and Mahila dairy farm, Harnath ki dhani (85 km. from H.Q.), Chomu Tehsil in Jaipur district of Rajasthan state. Geographically Jobner is located 45.0 k.m. West of Jaipur at $26^{\circ} 05^{\prime}$ North latitude, $75^{\circ}$ $28^{\prime}$ East longitudes and at an altitude of 427 meter above sea level.

\section{Plan of work}

The entire farm had similar management during the study period. The system of housing and type of labour as well as all managemental practices were similar at three selected dairy farms.

\section{Period of study}

The study was conducted from $16^{\text {th }}$ November, 2015 to $13^{\text {th }}$ February, 2016. The observations for the daily routine work on the farm (excluding milking operations) were recorded for a period of 90 days. Milking and associated operations were observed and noted for a period of 60 days, during the above duration.

\section{Animals used in the study}

The study was conducted on the Labour utilization pattern in management of various 
categories of cattle. All six categories of animals were present at selected dairy farms and selection of different breeds for comparison of labour utilization pattern among the breeds. Animals were divided in 6 groups i.e. Milch $\left(\mathrm{G}_{1}\right)$, Pregnant $\left(\mathrm{G}_{2}\right)$, Dry animal $\left(\mathrm{G}_{3}\right)$, Calves $\left(\mathrm{G}_{4}\right)$, Heifers $\left(\mathrm{G}_{5}\right)$ and Bull and Bullock $\left(\mathrm{G}_{6}\right)$.

The time taken for milking, cleaning, feeding and miscellaneous works was recorded. The total herd strength was 210 animals at different three dairy farm. The bull and bullocks were not present at Mahila dairy farm because of the availability of A.I. and tractor. During the study period, the average effective herd strength of different dairy farms is given in table 1 .

\section{Housing of the animals}

The housing system adopted at different dairy farms was loose housing as well as conventional barn.

\section{Number of labourers involved}

Labour required for smooth running of dairy farms. Two types of Labour

1. Skilled labour were working specific work i.e. farm mechanism and milking etc.

2. Unskilled labour was working normal work i.e. cleaning, harvesting etc.

Engaging two types of labour (a) Temporary and permanent as well as male and female. The one labour unit was calculated as one adult unit. Labour resources are of two kinds fixed and variable. Fixed labour is labour, which is used on farm throughout the year, it includes both permanent workers and family labour. Variable labour is labour used on seasonal basis, i.e. casual labour that can be hired when needed. The labour strength was
10, 14 and 5 at SKN COA, Agrim and Mahila dairy farm, respectively, but average daily present of working labour was 6 out of 10 at SKN COA dairy farm due to $\mathrm{GH}$, Leave and CCL as per govt. rules. The strength of labour is described in tables 2 and 3.

\section{Daily operation schedule}

The various activities are carried out on the dairy farms routinely (daily or periodically), there should be well planned and carried out punctually. It is ideal to draw up a schedule of dairy farm operations performed for each farm so that the personnel working on farm can carry out various operations at regular timing. A model of such schedule is given in table 4 .

\section{Recording of time taken for various activities}

The data were recorded without disturbing the normal ongoing routine activities of the farm. The labours engaged in the livestock farm activities were also not conscious about the recording of data.

The study was carried out on different groups of animals, which were basically categorized according to their age or status of animals. These animals were maintained in different sheds of the farm according to their groups.

The animals were divided into six groups. The various operations performed were milking, washing the animals, cleaning the shed, feeding, watering and miscellaneous works.

The miscellaneous works included deworming, vaccination, dehorning, A.I and treatment of animals. In case of bulls grooming the skin, exercise and servicing were also included. 


\section{Milking operation}

The milking was done manually and machine milking in two shifts as morning and evening. Cows were milked twice a day at 4.00 A.M. and 4.00 P.M. in the milking parlour. Sixty percent of cows were milked by hand and $40 \%$ by machine. Time was recorded both for hand milking and machine milking of cows as given below:-

\section{Animal tying and release time}

The time (minutes) spent for tying and releasing of animal in the milking shed was recorded.

\section{Calf handling during milking and milk suckling by calf}

The time (minutes) taken by the calf to suckle its dam before milking, time spent for washing of udder, time spent for bringing calf from calf pen to its dam in the milking barn and taking back to calf pen after suckling were recorded.

Attachment and detachment of milking machine

The time (minutes) spent for attaching and detaching the milking machine cluster to the individual teats of the cow was recorded (during machine milking).

\section{Actual milking time per milking}

The time (minutes) spent for complete milking of the animals for both by hand and machine milking was recorded.

\section{Weighing the milk, loading and unloading milk can}

The time (minutes) spent in weighing the milk, loading the milk filled cans and unloading the empty milk cans from the vehicle was recorded.

\section{Washing of milking machine and cleaning of can}

The time (minutes) spent for washing of milking machine and cleaning of can was recorded.

\section{Cleaning and washing of shed}

The time (minutes) spent in removal of dung, left over refusal and cleaning the floor of the shed as well as time spent for grooming and washing of animals was recorded. The collection and lifting of dung and agricultural refuge was basically done manually with a shovel. Broom sticks/water spraying was used for the cleaning operation.

\section{Feeding of the animals}

Feeding time (minutes) was recorded as the time spent for distribution of concentrate, green and dry fodder to various categories of animals in different sheds.

\section{Miscellaneous works}

The time (minutes) spent for the miscellaneous work viz. treatment, deworming, A.I. and vaccination was noted.

\section{Total working time}

Total working time was deduced by adding the time taken for various activities as indicated above. For milch animals, time taken for milking operation was also included in the total time. Based on the total time spent on each operation and for different categories of animals, number of manminutes/animal/day for each operation was calculated.

\section{Be manage by one labour unit}

The compute time taken for carrying out different activities and various categories of animal can be managed by one labour 
unit/a.u./day. The man power received was evaluated on a unit basis.

\section{Statistical analysis}

The data obtained from the study was analyzed by using statistical tools as per the procedure laid down by Snedkar and Cochran, 1994. The different statistical tools such as mean, standard error (SE) and coefficient of variance $(\mathrm{CV})$ were worked out to compare the data and interpret the results. Data was analyzed dairy wise, category wise in overall and compare of means by using statistical tool as simple tabular analysis, average, percentage and coefficient of variance $(\mathrm{CV})$ as and wherever necessary.

\section{Results and Discussion}

The present study was planned to evaluate the labour utilization pattern in management of various categories of cattle on different dairy farms. The study was conducted from $16^{\text {th }}$ November, 2015 to $13^{\text {th }}$ February, 2016 at SKN COA, dairy farm, Jobner, Agrim dairy farm, Kumbhpura and Mahila dairy farm, Harnath Ki Dhani. The observations for the daily routine work on the farm (excluding milking operations) were recorded for a period of 90 days. Milking operations were observed and noted for a period of 60 days, during the above duration. The result of experiment as the data collected during the experiment was subjected to standard methods of statistical analysis.

\section{Comparison of milking operations under different dairy farms}

Milking Operation consumed major share of time spent on milch cow. Hence it was felt appropriate to study in detail the time spent for various activities in cattle. The average time taken for tying the animal in milking parlour and releasing the animal from milking parlour at SKN, Agrim and Mahila dairy farm is presented in table 5. The average time taken for tying the animal in milking parlour and releasing the animal from milking parlour at SKN, Agrim and Mahila dairy farm was $3.29 \pm 0.062, \quad 3.01 \pm 0.036$ and $3.19 \pm 0.036$ $\mathrm{min} /$ animal/day, respectively.

The average time taken to bring the calf from calf pen to dam pen and taking back to the calf pen after suckling at SKN, Agrim and Mahila dairy farm is presented in table 5. The average time taken to bring the calf from calf pen to dam pen and taking back to the calf pen after suckling at SKN, Agrim and Mahila dairy farm was $2.58 \pm 0.09,2.27 \pm 0.031$ and $2.32 \pm 0.040 \mathrm{~min} / \mathrm{animal} / \mathrm{day}$, respectively. Similar findings were reported by Bara and Shah, 2012.

The average time taken for attachment and detachment of milking machine at SKN and Agrim dairy farm is presented in table 5. The average time taken for attachment and detachment of milking machine at SKN and Agrim dairy farm was $2.02 \pm 0.026$ and $2.00 \pm 0.022 \mathrm{~min} / \mathrm{animal} / \mathrm{day}$, respectively (Bara et al., 2012) reported less time in attachment and detachment of milking machine.

The average time taken for actual milking of the cows at SKN, Agrim and Mahila dairy farm is presented in table 5. The average time taken for actual milking of the cows at SKN, Agrim and Mahila dairy farm was $6.25 \pm 0.039, \quad 4.58 \pm 0.089$ and $6.86 \pm 0.054$ $\mathrm{min} / \mathrm{animal} /$ day, respectively.

The average time taken for weighing the milk at SKN, Agrim and Mahila dairy farm is presented in table 5. The average time taken in weighing the milk at SKN, Agrim and Mahila dairy farm was $1.50 \pm 0.027$, $1.37 \pm 0.022$ and $1.42 \pm 0.019 \mathrm{~min} /$ animal $/$ day, respectively. 
The average time taken for washing of milking machine and cleaning of can at SKN, Agrim and Mahila dairy farm is presented in table 5. The average time taken for washing of milking machine and cleaning of can at SKN, Agrim and Mahila dairy farm was $0.87 \pm 0.014, \quad 0.82 \pm 0.012$ and $0.55 \pm 0.011$ min/animal/day, respectively. The average total time taken in milking operations at different dairy farms is presented in table 5. The average total time taken in milking operations was lowest at Agrim dairy farm (14.05 $\pm 0.048 \mathrm{~min} / \mathrm{milch}$ animal/day) followed by Mahila dairy farm $(14.34 \pm 0.130 \mathrm{~min} / \mathrm{milch}$ animal/day) and at SKN COA, dairy farm (16.51 $\pm 0.076 \mathrm{~min} / \mathrm{milch}$ animal/ day). These findings are in agreement with those observed by (Sreedhar et al., 2009). The average time taken in milking operations was lowest at Agrim dairy farm than other dairy farms due to using good managemental practices and milking of cows using milking machine and large herd strength of dairy as well as mechanization system etc.

\section{Comparison of cleaning operation under different dairy farms}

The average time taken in cleaning operation at different dairy farms is presented in table 6 . The average time taken in cleaning operation was lowest at Agrim dairy farm (8.30 \pm 0.43 min/animal/day) followed by Mahila dairy farm $(8.68 \pm 0.46 \mathrm{~min} / \mathrm{animal} /$ day $)$ and $\mathrm{SKN}$
COA, dairy farm $(9.09 \pm 0.45 \mathrm{~min} / \mathrm{animal} / \mathrm{day})$. These findings are in agreement with those observed by Sreedhar et al., (2009).

Comparison of feeding and watering operation under different dairy farms

The average time taken in feeding and watering at different dairy farms is presented in table 7 . The average time taken in feeding and watering was lowest at Agrim dairy farm (8.85 $\pm 0.44 \mathrm{~min} /$ animal/day) followed by Mahila dairy farm $(9.19 \pm 0.48$ min/animal/day) and SKN COA, dairy farm (9.96 $\pm 0.68 \mathrm{~min} /$ animal/day). Similar findings were reported by (Bara et al., 2012). The average time taken in feeding and watering was lowest at Agrim dairy farm than other dairy farms due to good labour efficiency.

\section{Comparison of miscellaneous operation under different dairy farms}

The average time taken in miscellaneous work at different dairy farms is presented in table 8. The average time taken in miscellaneous work was lowest at Agrim dairy farm $(3.44 \pm 1.33 \mathrm{~min} / \mathrm{animal} /$ day $)$ followed by Mahila dairy farm $(3.70 \pm 1.29$ min/animal/day) and SKN COA, dairy farm $(4.63 \pm 1.65 \mathrm{~min} /$ animal/day). These findings are in agreement with those observed by Bara et al., (2012).

Table.1 Herd strength of various categories of animals at different dairy farms

\begin{tabular}{|c|c|c|c|c|}
\hline Groups & $\begin{array}{l}\text { Categories of } \\
\text { animals }\end{array}$ & $\begin{array}{c}\text { S.K.N Dairy } \\
\text { Farm } \\
\text { (Cross bred) }\end{array}$ & $\begin{array}{c}\text { Agrim Dairy } \\
\text { Farm } \\
\text { (Jersey) }\end{array}$ & $\begin{array}{c}\text { Mahila Dairy } \\
\text { Farm } \\
\text { (H.F.) }\end{array}$ \\
\hline $\mathrm{G}_{1}$ & Milch & 15 & 75 & 18 \\
\hline $\mathrm{G}_{2}$ & Pregnant & 03 & 15 & 04 \\
\hline $\mathrm{G}_{3}$ & Dry & 02 & 10 & 03 \\
\hline $\mathrm{G}_{4}$ & Calves & 04 & 16 & 06 \\
\hline $\mathrm{G}_{5}$ & Heifers & 06 & 20 & 07 \\
\hline \multirow[t]{2}{*}{$\mathrm{G}_{6}$} & Bulls \& Bullock & 03 & 04 & 02 \\
\hline & Total & 33 & 140 & 40 \\
\hline
\end{tabular}


Table.2 Categories of animals and daily working labour at different dairy farms

\begin{tabular}{llccc}
\hline \multirow{2}{*}{ Group } & Categories of animal & \multicolumn{3}{c}{ No. of labour working in groups } \\
\cline { 3 - 5 } & & SKN & Agrim & Mahila \\
\hline $\mathrm{G}_{1}$ & Milch cows & 2.0 & 6.0 & 1.5 \\
$\mathrm{G}_{2}$ & Pregnant cows & 1.0 & 2.0 & 1.0 \\
$\mathrm{G}_{3}$ & Dry & 0.5 & 1.0 & 0.5 \\
$\mathrm{G}_{4}$ & Calves & 0.5 & 2.0 & 0.5 \\
$\mathrm{G}_{5}$ & Heifers & 1.0 & 2.0 & 1.0 \\
$\mathrm{G}_{6}$ & Bulls and Bullock & 1.0 & 1.0 & 0.5 \\
\hline \multicolumn{2}{c}{ Total daily working labour } & $\mathbf{6 . 0}$ & $\mathbf{1 4}$ & $\mathbf{5 . 0}$ \\
\hline
\end{tabular}

Table.3 Type of labour at different dairy farms

\begin{tabular}{lccccccccc}
\hline Type of Labour & \multicolumn{3}{c}{ S.K.N dairy farm } & \multicolumn{3}{c}{ Agrim dairy farm } & \multicolumn{2}{c}{ Mahila dairy farm } \\
\cline { 2 - 10 } & Male & Female & Total & Male & Female & Total & Male & Female & Total \\
\hline Permanent & 09 & - & 09 & 08 & 02 & 10 & 02 & 02 & 04 \\
Temporary & 01 & - & 01 & 02 & 02 & 04 & 01 & - & 01 \\
Total & 10 & - & 10 & 10 & 04 & 14 & 03 & 02 & 05 \\
\hline
\end{tabular}

Table.4 Schedule of day-to-day operations on dairy farms

\begin{tabular}{|c|c|}
\hline Time (hours) & Farm operations \\
\hline $3.30-4.00$ & $\begin{array}{l}\text { 1.Cleaning of feed manger and removal of cow dung } \\
\text { 2. Feeding of dry fodder to milch cows } \\
\text { 3. Feeding concentrate ration just before milking }\end{array}$ \\
\hline $4.00-5.00$ & 2. Milking cows and weighing of milk of individual cow \\
\hline $5.00-5.30$ & 1. Distribution of the milk (in cans) \\
\hline $5.30-8.00$ & $\begin{array}{l}\text { 1. Releasing milch stock to loose house } \\
\text { 2. Cleaning of shed } \\
\text { 3. Feeding of dry fodder to dry and pregnant stock } \\
\text { 4. Washing and disinfection of milking barns }\end{array}$ \\
\hline $8.00-12.00$ & $\begin{array}{l}\text { 1. Cleaning of calf, dry stock, bullock and bull sheds } \\
\text { 2.Tying of milch stock } \\
\text { 3. Feeding concentrate ration to all category of animals } \\
\text { 4. Exercising and grooming of bulls }\end{array}$ \\
\hline $12.00-13.00$ & 1. Lunch cum rest period for labourers \\
\hline $13.00-15.00$ & $\begin{array}{l}\text { 1. Feeding concentrate to milch stock } \\
\text { 2. Removal of cow dung and cleaning of sheds } \\
\text { 3. Washing of milch stock }\end{array}$ \\
\hline $15.30-17.00$ & $\begin{array}{l}\text { 1. Feeding the other half of daily concentrate ration to milch cows just before milking } \\
\text { 2. Milking and weighing of milk of individual cow }\end{array}$ \\
\hline $17.00-18.30$ & $\begin{array}{l}\text { 1 Distribution of the milk (in cans) } \\
\text { 2. Washing and disinfection of can and milking room }\end{array}$ \\
\hline $18.30-3.30$ & 1. Night watchman duty \\
\hline
\end{tabular}


Table.5 Average time (min/animal/day) taken in different operations of milking in group G1 at different dairy farms

\begin{tabular}{|c|c|c|c|c|c|c|c|c|}
\hline \multirow[t]{2}{*}{ S.No. } & \multirow[t]{2}{*}{ Dairy farms } & \multicolumn{6}{|c|}{ Milking operation } & \multirow[t]{2}{*}{ Total } \\
\hline & & $\begin{array}{c}\text { Tying } \\
\text { \&Releasing } \\
\left(\mathrm{M}_{1}\right)\end{array}$ & $\begin{array}{c}\text { Calf } \\
\text { managed } \\
\text { at milking } \\
\left(\mathbf{M}_{2}\right)\end{array}$ & $\begin{array}{c}\text { Attachment } \\
\text { and } \\
\text { detachment } \\
\text { of milking } \\
\text { machine } \\
\left(M_{3}\right)\end{array}$ & $\begin{array}{c}\text { Actual } \\
\text { milking time } \\
\text { in hand/ } \\
\text { machine } \\
\text { milking } \\
\left(M_{4}\right)\end{array}$ & $\begin{array}{c}\text { Milk } \\
\text { weighing } \\
\text { time } \\
\left(M_{5}\right)\end{array}$ & $\begin{array}{l}\text { Washing of } \\
\text { milking } \\
\text { machine and } \\
\text { cleaning of } \\
\text { can } \\
\left(\mathrm{M}_{6}\right)\end{array}$ & \\
\hline 1 & $\begin{array}{l}\text { SKN COA, } \\
\text { dairy }\end{array}$ & $\begin{array}{c}3.29 \pm 0.062 \\
(7.37)\end{array}$ & $\begin{array}{c}2.58 \pm 0.090 \\
(7.38)\end{array}$ & $\begin{array}{l}2.02 \pm 0.026 \\
(5.21)\end{array}$ & $\begin{array}{c}6.25 \pm 0.039 \\
(3.70)\end{array}$ & $\begin{array}{c}1.50 \pm 0.027 \\
(1.74)\end{array}$ & $\begin{array}{c}0.87 \pm 0.014 \\
(6.49)\end{array}$ & $\begin{array}{c}16.51 \pm 0.076 \\
(0.92)\end{array}$ \\
\hline 2 & Agrim dairy & $\begin{array}{c}3.01 \pm 0.036 \\
(4.76)\end{array}$ & $\begin{array}{c}2.27 \pm 0.031 \\
(5.44)\end{array}$ & $\begin{array}{c}2.00 \pm 0.022 \\
(4.31)\end{array}$ & $\begin{array}{c}4.58 \pm 0.089 \\
(7.57)\end{array}$ & $\begin{array}{c}1.37 \pm 0.022 \\
(2.97)\end{array}$ & $\begin{array}{c}0.82 \pm 0.012 \\
(6.23)\end{array}$ & $\begin{array}{c}14.05 \pm 0.048 \\
(0.69)\end{array}$ \\
\hline 3 & Mahila dairy & $\begin{array}{c}3.19 \pm 0.036 \\
(4.46)\end{array}$ & $\begin{array}{c}2.32 \pm 0.040 \\
(6.84)\end{array}$ & $0.00 \pm 0.000$ & $\begin{array}{c}6.86 \pm 0.054 \\
\quad(3.10)\end{array}$ & $\begin{array}{c}1.42 \pm 0.019 \\
(2.11)\end{array}$ & $\begin{array}{c}0.55 \pm 0.011 \\
(8.42)\end{array}$ & $\begin{array}{c}14.34 \pm 0.130 \\
(1.81)\end{array}$ \\
\hline
\end{tabular}

Figures in parenthesis are represent to coefficient of variance (CV \%)

Table.6 Average time (min/animal/day) taken for cleaning under different groups of animals at dairy farms

\begin{tabular}{|c|c|c|c|c|c|c|c|c|}
\hline \multirow[t]{2}{*}{ S.No. } & \multirow[t]{2}{*}{ Dairy farms } & \multicolumn{6}{|c|}{ Groups } & \multirow[t]{2}{*}{ Average } \\
\hline & & $\mathbf{G}_{1}$ & $\mathbf{G}_{2}$ & $\mathbf{G}_{3}$ & $\mathbf{G}_{4}$ & $\mathbf{G}_{5}$ & $\mathbf{G}_{6}$ & \\
\hline 1 & SKN dairy & $\begin{array}{c}10.71 \pm 0.062 \\
(2.25)\end{array}$ & $\begin{array}{c}8.88 \pm 0.076 \\
(3.37)\end{array}$ & $\begin{array}{c}8.00 \pm 0.080 \\
(3.89)\end{array}$ & $\begin{array}{c}7.75 \pm 0.079 \\
(3.97)\end{array}$ & $\begin{array}{c}9.75 \pm 0.075 \\
(3.02)\end{array}$ & $\begin{array}{c}9.45 \pm 0.069 \\
(2.87)\end{array}$ & $\begin{array}{c}09.09 \pm 0.45 \\
(12.26)\end{array}$ \\
\hline 2 & Agrim dairy & $\begin{array}{c}09.85 \pm 0.058 \\
(2.31)\end{array}$ & $\begin{array}{c}7.90 \pm 0.073 \\
(3.61)\end{array}$ & $\begin{array}{c}7.25 \pm 0.060 \\
\quad(3.25)\end{array}$ & $\begin{array}{c}7.10 \pm 0.066 \\
\quad(3.71)\end{array}$ & $\begin{array}{c}8.95 \pm 0.069 \\
(3.00)\end{array}$ & $\begin{array}{c}8.75 \pm 0.077 \\
\quad(3.42)\end{array}$ & $\begin{array}{c}8.30 \pm 0.43 \\
(12.89)\end{array}$ \\
\hline 3 & Mahila dairy & $\begin{array}{c}10.35 \pm 0.046 \\
(1.75)\end{array}$ & $\begin{array}{c}8.45 \pm 0.047 \\
(2.20)\end{array}$ & $\begin{array}{c}7.50 \pm 0.058 \\
(3.01)\end{array}$ & $\begin{array}{c}7.32 \pm 0.054 \\
(2.87)\end{array}$ & $\begin{array}{c}9.25 \pm 0.066 \\
(2.78)\end{array}$ & $\begin{array}{c}9.22 \pm 0.045 \\
(1.91)\end{array}$ & $\begin{array}{c}08.68 \pm 0.46 \\
(13.33)\end{array}$ \\
\hline
\end{tabular}

Figures in parenthesis are represent to coefficient of variance (CV \%) 
Table.7 Average time (min/animal/day) taken for feeding and watering under different groups of animals at dairy farms

\begin{tabular}{|c|c|c|c|c|c|c|c|c|}
\hline \multirow[t]{2}{*}{ S.No. } & \multirow[t]{2}{*}{ Dairy farms } & \multicolumn{6}{|c|}{ Groups } & \multirow[t]{2}{*}{ Average } \\
\hline & & $\mathbf{G}_{1}$ & $\mathbf{G}_{2}$ & $\mathbf{G}_{3}$ & $\mathbf{G}_{4}$ & $\mathbf{G}_{5}$ & $\mathbf{G}_{6}$ & \\
\hline 1 & SKN dairy & $\begin{array}{c}12.18 \pm 0.061 \\
(1.96)\end{array}$ & $\begin{array}{c}9.05 \pm 0.078 \\
(3.37)\end{array}$ & $\begin{array}{c}8.05 \pm 0.071 \\
(3.49)\end{array}$ & $\begin{array}{c}8.79 \pm 0.072 \\
(3.18)\end{array}$ & $\begin{array}{c}11.75 \pm 0.063 \\
(2.07)\end{array}$ & $\begin{array}{c}9.98 \pm 0.058 \\
(2.28)\end{array}$ & $\begin{array}{c}09.96 \pm 0.68 \\
(16.81)\end{array}$ \\
\hline & Agrim dairy & $\begin{array}{c}10.06 \pm 0.063 \\
(2.43)\end{array}$ & $\begin{array}{c}8.27 \pm 0.070 \\
(3.31)\end{array}$ & $\begin{array}{c}7.45 \pm 0.065 \\
(3.43)\end{array}$ & $\begin{array}{c}7.94 \pm 0.067 \\
(3.28)\end{array}$ & $\begin{array}{c}9.78 \pm 0.063 \\
(2.53)\end{array}$ & $\begin{array}{l}9.60 \pm 0.12 \\
(5.35)\end{array}$ & $\begin{array}{c}\mathbf{0 8 . 8 5} \pm 0.44 \\
(12.39)\end{array}$ \\
\hline 3 & Mahila dairy & $\begin{array}{c}10.78 \pm 0.101 \\
(3.70)\end{array}$ & $\begin{array}{c}8.53 \pm 0.076 \\
(3.50)\end{array}$ & $\begin{array}{c}7.86 \pm 0.108 \\
(5.35)\end{array}$ & $\begin{array}{c}8.15 \pm 0.089 \\
(4.27)\end{array}$ & $\begin{array}{c}10.22 \pm 0.062 \\
(2.39)\end{array}$ & $\begin{array}{c}9.64 \pm 0.11 \\
(4.87)\end{array}$ & $\begin{array}{c}09.19 \pm 0.48 \\
(12.93)\end{array}$ \\
\hline
\end{tabular}

Figures in parenthesis are represent to coefficient of variance (CV \%)

Table.8 Average time (min/animal/day) taken for miscellaneous work under different groups of animals at dairy farms

\begin{tabular}{|c|c|c|c|c|c|c|c|c|}
\hline \multirow[t]{2}{*}{ S.No. } & \multirow{2}{*}{$\begin{array}{l}\text { Dairy } \\
\text { farms }\end{array}$} & \multicolumn{6}{|c|}{ Groups } & \multirow[t]{2}{*}{ Average } \\
\hline & & $\mathbf{G}_{1}$ & $\mathbf{G}_{2}$ & $\mathbf{G}_{3}$ & $\mathbf{G}_{4}$ & $\mathbf{G}_{5}$ & $\mathbf{G}_{6}$ & \\
\hline 1 & SKN dairy & $\begin{array}{c}1.68 \pm 0.281 \\
(28.90)\end{array}$ & $\begin{array}{c}9.63 \pm 0.090 \\
(3.59)\end{array}$ & $\begin{array}{c}3.80 \pm 0.073 \\
(3.34)\end{array}$ & $\begin{array}{c}1.06 \pm 0.206 \\
(33.51)\end{array}$ & $\begin{array}{c}1.80 \pm 0.320 \\
(30.69)\end{array}$ & $\begin{array}{c}9.84 \pm 0.199 \\
(3.50)\end{array}$ & $\begin{array}{c}04.63 \pm 1.65 \\
(87.62)\end{array}$ \\
\hline 2 & Agrim dairy & $\begin{array}{c}0.97 \pm 0.043 \\
(7.66)\end{array}$ & $\begin{array}{c}6.04 \pm 0.142 \\
(4.76)\end{array}$ & $\begin{array}{c}2.15 \pm 0.140 \\
\quad(11.27)\end{array}$ & $\begin{array}{l}0.94 \pm 0.208 \\
\quad(38.12)\end{array}$ & $\begin{array}{c}1.71 \pm 0.139 \\
(14.10)\end{array}$ & $\begin{array}{c}8.87 \pm 0.110 \\
\quad(2.15)\end{array}$ & $\begin{array}{c}03.44 \pm 1.33 \\
(95.00)\end{array}$ \\
\hline 3 & $\begin{array}{l}\text { Mahila } \\
\text { dairy }\end{array}$ & $\begin{array}{c}1.57 \pm 0.247 \\
(27.23)\end{array}$ & $\begin{array}{c}6.16 \pm 0.106 \\
(4.98)\end{array}$ & $\begin{array}{c}2.83 \pm 0.087 \\
(5.33)\end{array}$ & $\begin{array}{l}0.98 \pm 0.221 \\
(39.03)\end{array}$ & $\begin{array}{l}1.73 \pm 0.208 \\
(20.83)\end{array}$ & $\begin{array}{c}8.96 \pm 0.12 \\
(2.35)\end{array}$ & $\begin{array}{c}03.70 \pm 1.29(85 . \\
60)\end{array}$ \\
\hline
\end{tabular}

Figures in parenthesis are represent to coefficient of variance $(\mathrm{CV} \%)$

Table.9 Average total working time (min /animal/day) taken under different groups of dairy animals at dairy farms

\begin{tabular}{llcccccc}
\hline S.No & Dairy farms & \multicolumn{3}{c}{ Groups } & \multicolumn{2}{c}{ Average } \\
\cline { 3 - 7 } & & $\mathbf{G}_{\mathbf{1}}$ & $\mathbf{G}_{\mathbf{2}}$ & $\mathbf{G}_{\mathbf{3}}$ & $\mathbf{G}_{\mathbf{4}}$ & $\mathbf{G}_{\mathbf{5}}$ & $\mathbf{G}_{\mathbf{6}}$ \\
\hline 1 & SKN dairy & 41.08 & 27.56 & 19.84 & 17.59 & 23.30 & 29.27 \\
2 & Agrim dairy & 34.93 & 22.21 & 16.85 & 15.98 & 20.44 & 27.22 \\
3 & Mahila dairy & 37.04 & 23.14 & 18.19 & 16.45 & 21.20 & 27.82 \\
\hline
\end{tabular}


Table.10 Average total working time (min/labour/day) taken for various activities of different categories at different dairy farms

\begin{tabular}{|c|c|c|c|c|c|c|c|}
\hline S.No. & Dairy farms & $\begin{array}{c}\text { Total milking } \\
\text { time }\end{array}$ & $\begin{array}{c}\text { Total cleaning } \\
\text { time }\end{array}$ & $\begin{array}{l}\text { Total feeding } \& \\
\text { watering time }\end{array}$ & $\begin{array}{c}\text { Miscellaneous } \\
\text { work time }\end{array}$ & $\begin{array}{c}\text { Total working } \\
\text { time }\end{array}$ & $\begin{array}{c}\text { Total working time } \\
\text { spent/labour/day }\end{array}$ \\
\hline 1 & SKN dairy & 0247.65 & 0321.20 & 0376.34 & 106.25 & 1051.44 & $\begin{array}{c}175.24 \\
(2.55 \mathrm{hr} .)\end{array}$ \\
\hline 2 & Agrim dairy & 1053.75 & 1258.06 & 1314.86 & 269.57 & 3896.24 & $\begin{array}{c}278.30 \\
(4.38 \mathrm{hr} .)\end{array}$ \\
\hline 3 & Mahila dairy & 0258.12 & 0369.79 & 0391.65 & 097.26 & 1116.82 & $\begin{array}{c}223.36 \\
(3.43 h r .)\end{array}$ \\
\hline
\end{tabular}

Table.11 Average manage of animal/labour/day in different groups at different dairy farms

\begin{tabular}{|c|c|c|c|c|c|c|c|}
\hline \multirow[t]{2}{*}{ S.No. } & \multirow[t]{2}{*}{ Dairy farms } & \multicolumn{6}{|c|}{ Groups } \\
\hline & & $\mathbf{G}_{1}$ & $\mathbf{G}_{2}$ & $\mathbf{G}_{3}$ & $\mathbf{G}_{4}$ & $\mathbf{G}_{5}$ & $\mathbf{G}_{6}$ \\
\hline 1 & SKN dairy & $11.68(11-13)$ & $17.41(16-18)$ & $24.19(23-25)$ & $27.28(26-28)$ & $20.60(20-22)$ & $16.39(15-17)$ \\
\hline 2 & Agrim dairy & $13.74(13-15)$ & $21.61(21-23)$ & $28.48(27-29)$ & $30.03(29-31)$ & $23.48(23-25)$ & $17.64(17-19)$ \\
\hline 3 & Mahila dairy & $12.95(12-14)$ & $20.73(20-22)$ & $26.38(25-27)$ & $29.17(28-30)$ & $22.64(22-24)$ & $17.25(16-18)$ \\
\hline
\end{tabular}


Comparison of total working time/animal under different dairy farms

The average total working time taken at different dairy farms is presented in table 9 . The average total working time was lowest at Agrim dairy farm (34.64 min/animal/day) followed by Mahila dairy farm (35.91 $\mathrm{min} / \mathrm{animal} /$ day) and at SKN COA, dairy farm (40.19 min/animal/day).

\section{Comparison of total working time/labour under different dairy farms}

The average total working time per labour per day taken for various activities at different dairy farms is presented in table 10. The average total working time for various activities was highest at Agrim dairy farm (278.30 $\mathrm{min} /$ labour/day) followed by Mahila dairy farm (223.36 $\mathrm{min} /$ labour/day) and at SKN COA, dairy farm (175.24 $\mathrm{min} /$ labour/day). The labour utilization efficiency was highest in Jersey followed by H.F. than cross breed animals. Time taken for various milking activities among the different breeds (H.F., Jersey and Crossbred) varied in accordance with the milk yield and breed characteristics of the breeds. The time taken for feeding, cleaning and miscellaneous activities in different categories of the animals studied depended on the number of animal units, type of housing and method of feeding in each shed.

\section{Labour utilization efficiency under different dairy farms}

Labour utilization Efficiency under different dairy farms is presented in table 11. The labour utilization efficiency was highest at Agrim dairy farm (one labour can manage 1315 milch cows, 21-23 pregnant, 27-29 dry, 29-31 calf, 23-25 heifers and 17-19 bull and bullocks) followed by Mahila dairy farm (one labour can manage 12-14 milch cows, 20-22 pregnant, 25-27 dry, 28-30 calf, 22-24 heifers and 16-18 bull and bullocks) and at SKN COA dairy farm (one labour can manage 1113 milch cows, 16-18 pregnant, 23-25 dry, 26-28 calf, 20-22 heifers and 15-17 bull and bullocks). Labour requirement of a dairy farm depends upon various factors viz. the efficiency of labourers, species, type and number of animals maintained, feeding practices, the design of animal housing, the degree of mechanization etc. Similar findings were reported by Devarajulu et al., (1989) regarding milch and dry animals.

\section{References}

Anonymous. 2012. $19^{\text {th }}$ Livestock Census all India report. Ministry of Agriculture Department of Animal Husbandry, Dairying and Fisheries. Krishi Bhawan, New Delhi. 11- 23.

Bara, P.S. and Shah, S.V. 2012. Labour utilization pattern on a dairy farm. Research Highlights, Department of Livestock Production \& Management, (AAU, Anand). P. 143-144.

Devarajulu, D. and Narasaiah K. Naidu. 1989. Time motion studies of some dairy farm operations. Indian J. Dairy Sci., 42(3): 471-474.

Grewal, S.S. and Rangi, P.S. 1980. Economics and employment of dairying in Punjab. Indian J. Agri. Economics, 35(4): 120-125.

Legha, R.A. and Tomar, O.S. 2000. Man power utilization in growing crossbred females under different management systems of housing and feeding. Indian J. Animal Production and Management, 16: 15-17.

Rawat, B.S., Singh, S. and Khajuria, R.R. 1973. Time and motion study for the work of hand milking of cows. Indian Vet. J., 50(3): 241-245.

Singh and Dave. 1985. Labour utilization pattern in dairy farm operation. Indian 
J. Animal Sci., 55: 615

Snedkar, G.W. and Cochran, W.G. 1994. Statistical method. $8^{\text {th }}$ Edn. Iowa, State

University Press. Ames, Iowa.
Labour utilization pattern in management of various categories of dairy animals. Indian J. Animal Res., 43(3): 187-190.

Sreedhar, S. and Ranganadham, M. 2009.

\section{How to cite this article:}

Rashmi Bhinda, R.P. Jat, Bajarang Lal Choudhary and Basant Kumar Bhinchhar. 2017. Comparison between Average Time Taken in Different Groups of Cattle under Various Activities at Different Dairy Farm in Jaipur District, Rajasthan. Int.J.Curr.Microbiol.App.Sci. 6(8): 1818-1829. doi: https://doi.org/10.20546/ijcmas.2017.608.214 